\title{
An Investigation of the Relationship between EFL Learners' Use of Oral Compensation Strategies and their Personal Stamina
}

\author{
By \\ Karima Mohammad Abd El-Aziz \\ (Assistant lecturer at the Curricula and Instruction Department) \\ Supervised by \\ Education and Students' Affairs \\ Faculty of Education - Fayoum \\ University \\ Dr. Ragaa Attalla Hanna \\ Emeritus Professor of Curricula \\ and English Language \\ Instruction - Faculty of \\ Education - Fayoum University
}

Dr. Mohammad Farouk Abd-El Samie

Professor of Curricula and English anguage Instruction and Vice Dean of

\section{Dr. Mona Ahmed Abdel Tawab}

Lecturer of Curricula and English Language Instruction

Faculty of Education - Fayoum University 
The Investigation of the Relationship between EFL Learners' Use of Oral Compensation Strategies and their Personal Stamina

\section{Abstract}

The current study aimed at investigating the compensation strategies used by EFL learners and the relationship between use of these strategies and learners' personal stamina. Sample of the study consisted of 30 third year English section students at the Faculty of Education, Fayoum University. Data collection instruments included: (1) personal stamina sub-scale, and (2) an oral interview. The quantitative and qualitative methods were applied in the current study: the quantitative method was used for counting the frequency of use and percentages of compensation strategies, and finding out the correlation between learners' frequency of use of these strategies and personal stamina (Pearson Co-efficient was used for correlation analysis). The qualitative method was used in transcribing the recorded data obtained from the oral interview, in order to identify the compensation strategies used by the study sample while doing the oral tasks. Results of the study showed that (1) the most frequently used compensation strategy was "use of pause fillers" (53.7\%), followed by "use of repetition" (15.06 \%), " use of false starts" (8.08\%), " Self-repair" (7.8\%), "circumlocution" (7.4\%), "substitution" (3.54\%), "word coinage" (1.7 $\%)$, and "literal translation" (1.2\%). The least frequently used strategies were "exemplification" (0.11\%), "generalization" (0.66 \%), and "message abandonment" (0.78 \%), and (2) there was a positive statistically significant correlation at (0.01) level between learners' frequency of use of compensation strategies and personal stamina. Some recommendations and suggestions for further research were given.

Key words: language learning strategies, compensation strategies, personal stamina. 


\section{Introduction}

Language learning strategies contribute to the processes learners apply to enhance their competency in using the foreign language. In the past decades, attention had changed from the teacher to the student. As stated by Chang and Lee (2007) no single teaching method could guarantee absolute and predicable success in second or foreign language teaching; some learners seem to be successful at the foreign language regardless of teaching methods or techniques. Therefore, a considerable number of researchers have shifted their focus from teaching methods or techniques to language learning strategy use. According to Karbalaei and Taji (2014), there is a focus on learner strategies, especially those used by good language learners, because once these strategies are clarified and successfully instructed to learners of lower competency, they could have notable effect for increasing the improvement of language skills.

Compensation strategies are a sub-category of language learning strategies. They are "strategies which a language user employs in order to achieve his intended meaning when precise linguistic forms are, for some reasons, not available at that point of communication" (Taheri and Davoudi, 2016). The use of compensation strategies is inevitable for native as well as non-native speakers, but they are used more by non-native speakers of the language. This is because no individual's linguistic repertoire is perfect. Compensation strategies are inevitable in oral communication for language learners. These strategies keep speakers flexible and confident, and make their communication more effective (Mottrian \& Tahriarian, 2013). The development of students' use of compensation strategies is a way of enhancing their communicative competence. Furthermore, training students in the use of these strategies will make them more autonomous and it will facilitate the task of using the foreign language, especially for those who lack confidence in their resources or those who are less capable linguistically. Compensation strategies provide these students with alternative means to convey their message without having to use the exact words in order to communicate effectively (Manchon, 2000).

Most studies done in the field of compensation strategies have been conducted for classifying the strategies (e.g., Tarone, 1980; Dorniey, 1995; 
Dornyei and Scott, 1997), and for examining the compensation strategies learners actually use (e.g. Somsai, 2011; Yaman, Irgin \& Kavasoglu, 2013; Hua, 2012; Ugla; Adnan; Jafre and Abidin, 2013; Wahyuni, 2013, Rodríguez, 2012; Kaizhu, 2016; AL-Saqqaf, 2015).

A construct closely related to the use of language strategies in general is learners' linguistic self-efficacy or, as stated by Bandura (1982), "the person's judgment of the ability to organize and execute given types of performance required for doing language tasks". People with high level of self-efficacy are confident in facing challenging situations, handling obstacles, creating ideas and solving problems. So, if a student of the English Language acquires high level of self-efficacy, he/she will be competent in the use of the English Language. Bandura identified self-efficacy as one of the critical factors motivating people to engage in pursuing their goals. The development of self-efficacy, then, is tied to the concept of empowerment, and the idea of taking control of one's life, or being the master of one's own destiny. According to Topkaya (2010), the most significant effect of selfefficacy beliefs on human behavior is their influence on people's decisions, goals, their amount of effort in conducting a task, and the length of time they would preserve through obstacles and difficulties". So, personal stamina is a component of self-efficacy; it is concerned with the learner's beliefs about the ability to work on tasks for a long time, and try hard to overcome obstacles and difficulties.

Research in linguistic self-efficacy (e.g. Mizumoto, 2012; Gahungu, n.d.; Li and Wang, 2010; Hamedani, 2013) showed that there is a positive relationship between EFL learners' use of language learning strategies in general and their self-efficacy beliefs. Research done for investigating the relationship between compensation strategies, in particular and different components of linguistic self-efficacy is still lacking.

So, investigation of the compensation strategies EFL learners use is very important in order to find out whether they use effective or ineffective strategies, especially that this point is not given the suitable interest within the Egyptian context. Furthermore, investigation of the variables that may affect the use of compensation strategies is necessary, especially that these strategies are inevitable for learners of English as a foreign language as they 
have a lot of language limitations. So, the aim of the current study was to investigate whether EFL learners' use of compensation strategies is related to their personal stamina, especially that most of the research done in this area focused on the relationship between the use of language learning strategies in general and linguistic self-efficacy.

\section{Statement of the problem}

In spite of the importance of oral compensation strategies, learner's use of these strategies is not given enough emphasis, especially in the Egyptian context. So, the aim of the current study was to investigate the compensation strategies EFL learners use and the relationship between frequency of use of these strategies and learners' personal stamina.

\section{The problem of the study is stated in the the following questions.}

○ What are the compensation strategies most frequently used by EFL learners?

O What is the correlational relationship between personal stamina and the frequency of use of oral compensation strategies?

\section{Hypotheses of the study}

o There is a statistically significant correlational relationship between use of oral compensation strategies and personal stamina.

\section{Purpose of the study}

The purpose of the current study was to investigate the correlational relationship between use of oral compensation strategies and personal stamina.

\section{Significance of the study}

\section{The current study may contribute in:}

o Introducing a reliable measure of personal stamina that will help EFL learners investigate their level of stamina regarding the use of language. 
o Introducing a list of compensation strategies that can help researchers and learners find out about the strategies EFL learners may use while communicating in English.

o Providing researchers in the field of EFL instruction with information about the compensation strategies EFL learners actually use.

\section{Definition of terms}

\section{1. compensation strategies}

Compensation strategies are the strategies that help learners perform in the presence of oral communication deficiencies (Mottrian \& Tahriarian, 2013). Tarone (1980) stated that conscious compensation strategies are used by the speaker to overcome the crisis which occurs when language structures are inadequate to convey the individual's thought.

In the current study, compensation strategies are the strategies EFL learners use to fill gaps in communication when linguistic resources are inadequate.

\section{2. personal Stamina}

Personal stamina is a component of linguistic self-efficacy. It is defined as learners' beliefs about the amount of effort they can exert for conducting a task, and the length of time they would preserve through obstacles and difficulties (Topkaya (2010).

In the current study, the previous definition was adopted.

\section{$\underline{\text { Review of literature }}$}

A lot of research has been done in the area of investigating the compensation strategies used by EFL learners around the world. Hua, Nor, and Jaradat (2012), for example, investigated how and when compensation strategies were used in discussions by international students at Universiti Kebangsaan Malaysia, a public university in Malaysia. their study aimed to examine the differences in the use of 
compensation strategies between high and low proficient speakers. The participants were a group of ten low proficient Arabic speakers of English and a group of ten high proficient Chinese and Arabic speakers of English. Data were elicited from audio recordings of oral group discussions and a self-report. Findings showed that the subjects resorted to ten out of the twelve types of compensation strategies specified by Tarone (1980), Faerch and Kasper (1983), and Willems (1987). The most frequently employed compensation strategy was code switching; and the least used strategy was word coinage.

Also, Thu and Thu (2016) conducted a study that aimed at investigating the oral English compensation strategies used by Vietnamese non-English majors at intermediate level. Participants consisted of 20 non-English majors whose English proficiency is intermediate. For collecting data, participants were asked to participate in a group discussion and their oral discussions were recorded. The recordings were then transcribed for data analysis. A questionnaire suggested by Malasit and Sarobol (2013) was used to identify students' compensation strategies. Results showed that the use of pause fillers was the most frequently used strategy $(23.4 \%)$. It was followed by selfrepair (12.5\%), self-repetition (10\%), and code-witching (7.8\%) respectively.

Similar results were reached by Taheri and Davoudi (2016) who carried out a study to examine the compensation strategies used by EFL learners in English department of Iranian Academic Center for Education. The participants were interviewed individually and their performances were tape-recorded and then transcribed. The findings of the study indicated that "self-repetition", "direct appeal for help", and "approximation" were the most frequently used strategies.

Yilmaz (2010) carried out a study to investigate the English language learning strategies employed by English majors enrolled at Çanakkale Onsekiz Mart University in Turkey. For this purpose, a 
questionnaire was administered to 140 participants in the department of English Language Teaching. The results of the study showed, among other things that the highest rank (79.4\%) was for compensation strategies.

Ugla; Adnan; Jafre and Abidin (2013) carried out a study to investigate the compensation strategies used by Iraqi EFL students. The data analyzed in this study were collected in Baghdad University. For collecting data, a questionnaire was adopted from Dornyei and Scott's taxonomy of communication strategies (1995). Sample of the study consisted of fifty Iraqi EFL students. The results obtained showed that the most frequently used strategies were code switching and self-repair. Iraqi EFL students also used word-coinage, mime, approximation/generalization, literal translation, omission, message-reduction, use of all-purpose words, other repairs, selfrephrasing, circumlocution/paraphrase, restructuring, fillers, self-repetition, and message abandonment strategies moderately.

AL-Saqqaf (2015) conducted a study to identify the compensation strategies used most by Yemeni postgraduates in Malaysia. A compensation strategy inventory was developed based on the taxonomies given by Tarone (1977), Faerch and Kasper (1983), and Dornyei and Scott (1995). Results demonstrated that asking for repetition, self-repair, asking for clarification, circumlocution, meaning replacement, asking for confirmation, and selfrephrasing were the most frequently used strategies.

The relationship between the use of language learning strategies in general and compensation strategies in particular, and linguistic selfefficacy was also examined in research. For example, Wang and Wang (2015) carried out a study to investigate the relationship among EFL college learners' language learning strategies, English self-efficacy, and explicit strategy instruction. Three constructs, namely language learning strategies, English learning self-efficacy, and explicit strategy instruction, were investigated through a correlational and quasi-experiment study. The study revealed that there was a positive correlation between language learning strategies and English self-efficacy. 
Jee (2015) conducted a study to explore the relationship between strategy use (including compensation strategies) and linguistic-self-efficacy. Sample of the study consisted of 92 Korean language learners. For collecting data, a survey with 78 items for strategy use and self-efficacy was used. Results of the study showed, among other things, that there was a statistically significant positive correlation between strategy use and self-efficacy.

Zarei and Gilanian (2015) investigated the relationship between language learning strategies including compensation strategies and self-efficacy. Sample of the study consisted of 147 male and females students majoring in English translation and English language teaching. Instruments used for collecting data were: the Strategy Inventory for Language Learning (SILL), and a 12-item Self-efficacy scale. The results indicated a positive relationship between language learning strategies and self-efficacy.

Mizumoto (2012) carried out a study to examine the effects of selfefficacy on language learning strategies, by focusing on vocabulary learning strategies (VLSs). A group of 281 EFL university learners participated in the study. For collecting data, learners completed the Vocabulary Size Test, questionnaires on self-efficacy, and an open-ended question about their use of learning strategies. Results showed that students with high self-efficacy were active users of learning strategies. Those with low self-efficacy tended to be passive users of these strategies.

\section{$\underline{\text { Research Design }}$}

\section{1. participants}

The participants of the study were 30 third year English section students at the Faculty of Education, Fayoum University.

\section{Data Collection procedures}

For the purpose of the study, a scale was designed in order to collect data about the study sample's level of stamina. It was a sub-scale of the linguistic self-efficacy scale designed by the researcher. The linguistic self-efficacy scale as a whole was tested for validity and reliability. 


\section{Validity of the scale}

The linguistic self-efficacy scale was designed based on a review of literature. It was composed of four dimensions; self-confidence, stamina, self-regulation, and independence. Each of the four dimensions was defined operationally and based on that definition, statements were formulated for each dimension. Regarding the stamina sub-scale, it was composed of twelve statements. The first version of the scale was examined by a group of seven experts in English language methodology to judge it regarding the following points:

Relatedness of the items to the general dimension.

Clarity and wording of the statements.

The suitability of the scale for assessing EFL learners' level of stamina.

Some modifications were done in the scale based on the experts' suggestions. These modifications are shown in table (1) below.

Table (1)

Modifications in the stamina sub-scale

\begin{tabular}{c||l||l|}
\hline \hline $\mathbf{2 1}$ & $\begin{array}{l}\text { I can stand stable in front } \\
\text { of obstacles and problems. }\end{array}$ & $\begin{array}{l}\text { I can handle obstacles and } \\
\text { problems regarding my language } \\
\text { performance. }\end{array}$ \\
\hline \hline $\mathbf{2 3}$ & $\begin{array}{l}\text { I avoid speaking in topics I } \\
\text { know little about. }\end{array}$ & $\begin{array}{l}\text { I avoid participating in } \\
\text { difficult/unfamiliar language tasks. }\end{array}$ \\
\hline \hline
\end{tabular}

\section{Reliability of the scale}

The reliability of the scale was tested using the split half method. The scale was divided into two halves and correlation was calculated using Spearman Brown formula. The reliability level of the stamina sub-scale was found to be $\mathbf{( 0 . 8 4 )}$ which is a good reliability level. 
For collecting data about the frequency of use of compensation strategies, discourse analysis was used to analyze the responses of the study sample. For this purpose the below procedures were followed:

B The study participants were interviewed, and they were given three oral tasks, in the first task they were asked to describe their houses, in the second task they were asked to describe someone important to them, and in the third task they were asked to discuss a problem which is "unemployment". Students' responses were video-taped, and, later on, transcribed.

B A checklist of compensation strategies was designed based on Tarone's (1980), Farech and Kasper's (1983) and Dorniey and Scott's (1997) taxonomies of communication strategies.

B Transcriptions of the participants' responses were analyzed to find out the frequency of use of compensation strategies using the list below.

Table (2)

\section{Compensation strategies list}

\begin{tabular}{|c|l|}
\hline \multicolumn{1}{|c|}{ strategy } & \multicolumn{1}{|c|}{ definition } \\
abandongage & $\begin{array}{l}\text { Message abandonment occurs when the } \\
\text { learner begins to talk about a concept but } \\
\text { is unable to continue due to lack of } \\
\text { meaning structure, and stops in mid- } \\
\text { utterance. }\end{array}$ \\
\hline substitution & $\begin{array}{l}\text { Substitution occurs when the learner uses } \\
\text { a single target language vocabulary item } \\
\text { or structure, which the learner knows is } \\
\text { not correct, but shares enough semantic } \\
\text { features in common with the desired item } \\
\text { to satisfy the speaker. }\end{array}$ \\
\hline generalization & $\begin{array}{l}\text { Generalization is using a more general } \\
\text { word for an unknown word. }\end{array}$ \\
\hline exemplification & Giving an example of something for \\
\hline
\end{tabular}




\begin{tabular}{|c|c|}
\hline & which the learner does not know the word. \\
\hline Word coinage & $\begin{array}{l}\text { Word coinage is employed when the } \\
\text { learner makes up a new word in order to } \\
\text { communicate a desired concept. }\end{array}$ \\
\hline Circumlocution & $\begin{array}{l}\text { In circumlocution, the learner describes } \\
\text { the characteristics or elements of the } \\
\text { object or an action instead of using the } \\
\text { appropriate target language structure. }\end{array}$ \\
\hline $\begin{array}{c}\text { literal } \\
\text { translation }\end{array}$ & $\begin{array}{l}\text { In literal translation, the learner translates } \\
\text { word for word from the native language. }\end{array}$ \\
\hline Paraphrase & $\begin{array}{l}\text { The learner expresses the meaning of } \\
\text { something using different words, } \\
\text { especially to achieve greater clarity. }\end{array}$ \\
\hline $\begin{array}{c}\text { Use of } \\
\text { fillers/hesitation } \\
\text { devices }\end{array}$ & $\begin{array}{l}\text { It is using filling sounds and words to gain } \\
\text { time to think. Fillers are used to tell the } \\
\text { listener that you haven't finished, but you } \\
\text { are thinking of what to say next. Example } \\
\text { filler sounds and words are (hmm, ummm. } \\
\text { Uhhh, well, you know, you see, I mean, } \\
\text { the thing is...). }\end{array}$ \\
\hline Repetition & $\begin{array}{l}\text { In repetition, the learner repeats utterances } \\
\text { to give himself the chance to think of what } \\
\text { he/she is going to say next. }\end{array}$ \\
\hline Self-repair & $\begin{array}{l}\text { In self-repair, the learner corrects himself } \\
\text { when he/she has an incorrect language } \\
\text { item or structure. }\end{array}$ \\
\hline False starts & $\begin{array}{l}\text { False starts mean that the learner starts } \\
\text { talking one way, then he/she stops in mid- } \\
\text { utterance and starts again another way. }\end{array}$ \\
\hline
\end{tabular}




\section{$\underline{\text { Results }}$}

The current study aimed to examine the compensation strategies used by EFL learners while performing oral tasks, and to investigate the relationship between the frequency of use of these strategies and learners' personal stamina. For this purpose, qualitative and quantitative analysis of data were used. Qualitative analysis of data was used for analyzing students' discourse to examine the compensation strategies they used while doing oral tasks, while quantitative analysis was used for calculating the frequency of use of these strategies and finding out whether they are related to learners' personal stamina.

\section{Frequency of use of compensation strategies}

Regarding the frequency of use of compensation strategies, table (3) below shows the frequency of use and percentage of each strategy.

\section{Table (3)}

\section{Frequency of use and percentages of compensation strategies}

\begin{tabular}{l||c|c}
\hline \hline \multicolumn{1}{c|}{ Strategy } & $\begin{array}{c}\text { Frequency } \\
\text { of use }\end{array}$ & Percentage \\
\hline \hline Message abandonment & 7 & $0.78 \%$ \\
\hline \hline Substitution & 32 & $3.54 \%$ \\
\hline \hline Generalization & 6 & $0.66 \%$ \\
\hline \hline Exemplification & 1 & $0.11 \%$ \\
\hline \hline Word coinage & 16 & $1.7 \%$ \\
\hline \hline Circumlocution & 67 & $7.4 \%$ \\
\hline \hline
\end{tabular}




\begin{tabular}{l||c||c}
\hline \hline Literal translation & 10 & $1.2 \%$ \\
\hline \hline Use of fillers & 485 & $53.7 \%$ \\
\hline \hline Repetition & 136 & $15.06 \%$ \\
\hline \hline Self-repair & 70 & $7.8 \%$ \\
\hline \hline False starts & 73 & $8.08 \%$ \\
\hline \hline Total & $\mathbf{9 0 3}$ & $100 \%$ \\
\hline \hline
\end{tabular}

The above table shows that the most frequently used compensation strategy was "use of pause fillers" (53.7 \%), followed by "use of repetition" (15.06 \%), " use of false starts" (8.08 \%), " Self-repair" (7.8 $\%)$, "circumlocution" (7.4\%), "substitution" (3.54\%), "word coinage" $(1.7 \%)$, and "literal translation" $(1.2 \%)$. The least frequently used strategies were "Exemplification" (0.11 \%), "generalization" (0.66 \%), and "Message abandonment" (0.78\%).

\section{Examples of strategy use taken from the transcribed data}

\section{Pause fillers.}

Pause fillers are sounds, words, and phrases used by the speaker to save time to think of the next utterance without having to stop. For example:

1. My house is looking from $\underline{u h}$ in front of it $\underline{u h h}$ what's the word I'm looking for?

2. ummm_in comparison with our old house it's very uhhhh what's the word I'm looking for? uhhhh. Give me a minute to think uhhhh.

3. I think the solution to this problem, to uhhhh, ummmm, let me think please...

4. There is a mosque in front of it and we have a garden in front of it also. uummm, just a minute. According to the climate and the weather........

5. This problem is a very serious problem. $\underline{u h h, u m m m}$ it causes a lot of problems. $\underline{w h h}$, also, it is because of the lack of opportunities and the 
lack of $\underline{u h h h}$ uhhhhh the lack of job opportunities, and ummmm, give me a minute to think please

\section{Use of repetition}

Learners use repetition also to fill time to give themselves the chance to search for what to say next for example:

1. Sometimes he uhhhh, sometimes he exhausts himself in order to make us happy and comfortable

2. he has a mustache on his face, he has a mustache, his eyes are brown, are brown

3. the first part the first part contains reception and my brother's room

4. uhh she has ...she has uhhh beautiful, beautiful laugh.

5. She is uhh she is uhhh she is younger than me

\section{Use of false starts}

Using false starts means that the speaker starts talking about something and he/she starts talking one way, then he/she stops in mid-utterance and starts again another way. for example:

1. My father, if you look at him, for my father, according to him, he is a bold man

2. He is... I'm the only one in my family who enter a university

\section{Circumlocution}

In circumlocution, the speaker describes the characteristics or the meaning of the intended language item instead of having to mention the exact word. For example:

1. Also, she is unique uhh I don't know what's that word exactly, but she always wants to do something for the society, she always encourages me.

2. he is very careful and uhhh I can't remember the word exactly, but uhh he is very uhh when something like uhhh when something happen when something harmful will happen to my brothers or to me, he is very nervous uhh for that

3. he loves people who study, but at the same time he doesn't like to to what? yes to uhhh make my health poor for the sake of studying 
4. The first floor this floor we call it calf department_as_we every feast every big feast we can uhh not sacrifice we can ... you know ummm what's the word I'm looking for? Let me think, it is killing it, but it is acceptable killing.

\section{Self-repair}

In self-repair the speaker corrects his own utterances. For example:

1. It has also a table dressing, a dressing table and a very big mirror

2. the most room that contains that allows air to come

3. On the left hand ...the left right... the left hand...the left side of my room, you can find a kitchen...

4. a fan on the wall on the ceiling uhhh and air condition

II. The correlation between frequency of use of compensation strategies and personal stamina

For finding out whether there is a correlation between learners' frequency of use of compensation strategies and personal stamina, Pearson co-efficient was used. Results of the correlational analysis using the (SPSS) program showed that there is a positive statistically significant correlation between frequency of use of oral compensation strategies and learners' personal stamina. The correlation co-efficient was (0.93). This means that when learners have an enhanced level of personal stamina, they use compensation strategies more frequently. On the contrary, wen learners have a low level of personal stamina, they use compensation strategies less frequently. Results of the correlation analysis is shown in table (4) below.

\section{Table (4)}

The correlation between the frequency of use of compensation strategies and personal stamina

\begin{tabular}{c|c||c}
\hline \hline $\begin{array}{c}\text { Compensation } \\
\text { strategies }\end{array}$ & $\begin{array}{c}\text { Correlation } \\
\text { co-efficient }\end{array}$ & $\begin{array}{c}\text { Significance } \\
\text { level }\end{array}$ \\
\hline \hline Message & $\mathbf{0 . 1 0}$ & $\mathbf{0 . 5 9}$ \\
\hline \hline
\end{tabular}




\begin{tabular}{l||c|c}
\hline $\begin{array}{c}\text { Compensation } \\
\text { strategies }\end{array}$ & $\begin{array}{c}\text { Correlation } \\
\text { co-efficient }\end{array}$ & $\begin{array}{c}\text { Significance } \\
\text { level }\end{array}$ \\
\hline \hline abandonment & & \\
\hline \hline Substitution & $\mathbf{0 . 2 6}$ & $\mathbf{0 . 1 6}$ \\
\hline \hline Generalization & $\mathbf{0 . 0 7}$ & $\mathbf{0 . 7 1}$ \\
\hline \hline Exemplification & $\mathbf{0 . 0 1}$ & $\mathbf{0 . 5 9}$ \\
\hline \hline Word coinage & $\mathbf{- 0 . 0 9}$ & $\mathbf{0 . 6 5}$ \\
\hline \hline Circumlocution & $\mathbf{0 . 3 7}$ & $\mathbf{0 . 0 5}$ \\
\hline \hline Literal translation & $\mathbf{0 . 1 9}$ & $\mathbf{0 . 3 0}$ \\
\hline \hline paraphrase & $\mathbf{0 . 5 8}$ & $\mathbf{0 . 0 1}$ \\
\hline \hline Use of fillers & $\mathbf{0 . 7 3}$ & $\mathbf{0 . 0 1}$ \\
\hline \hline Repetition & $\mathbf{0 . 5 5}$ & $\mathbf{0 . 0 1}$ \\
\hline \hline Self-repair & $\mathbf{0 . 4 9}$ & $\mathbf{0 . 0 1}$ \\
\hline \hline False starts & $\mathbf{0 . 4 5}$ & $\mathbf{0 . 0 1}$ \\
\hline \hline
\end{tabular}

Although the correlation between the total score of the personal stamina scale and the frequency of use of compensation strategies was positively significant at (0.01), not all the strategies were significantly related to personal stamina. For example, the frequency of use of message abandonment, substitution, generalization, exemplification, word coinage, and literal translation was not related to learners' personal stamina. Other strategies (Circumlocution, paraphrase, Use of fillers, Repetition 
Self-repair, False starts) were positively significantly correlated to personal stamina.

\section{$\underline{\text { Discussion }}$}

The current study aimed to identify the compensation strategies used by EFL learners, and the relationship between frequency of use of these strategies and personal stamina.

Results of the study showed that the most frequently used strategies were "pause fillers", "use of repetition", "use of false starts", "Self-repair", "circumlocution", "substitution", and "word coinage", respectively. Learners resorted frequently to these particular strategies because they found that these strategies help them to compensate for their problems. In other words, learners have certain problems; accordingly, they selected these particular strategies. "Pause fillers" and "use of repetition" are primarily used to compensate for lack of fluency, and they give the speaker enough time to think of and organize ideas; so, learners used them frequently because most Arabic speakers of English have problems with generating and organizing ideas as well as speaking fluently. The researcher, while conducting her Ph.D. dissertation, conducted a pilot study to find out the problems EFL preservice teachers encounter while performing oral tasks, results of the pilot study showed that generating and organizing ideas were the most problematic areas for the participants: (66.7\%) and (62.9\%) respectively, followed by speaking fluently (54.8\%). Also, El-Sakka (2016) conducted a pilot study on thirty 3rd year English majors at the Faculty of Education, Suez Canal University to explore their speaking problems. Results of the pilot study showed that EFL university students are neither fluent nor confident English speakers. So, the current study sample used pause fillers and repetition more frequently because these strategies helped them compensate for their lack of fluency and gave them time to think of and organize ideas in a better way. Furthermore, results of the pilot study conducted by the 
researcher showed that lack of vocabulary is also a problematic area for EFL learners (43.3\%). So, it can be said that the current study sample had vocabulary problems, this caused them to resort to strategies for compensating for lack of vocabulary and structures such as circumlocution, substitution, word coinage, self-repair, and false starts.

Results of the current study are consistent with those reached by Thu and Thu (2016), Ugla; Adnan; Jafre and Abidin (2013), and ALSaqqaf (2015). These studies found out that "pause fillers", "use of repetition", "use of false starts", "Self-repair", "circumlocution", "substitution", and "word coinage", were used frequently by EFL learners.

Results of the study also showed that the study sample's use of compensation strategies was related to their personal stamina. Enhanced beliefs about their ability to work on tasks for a longer time, challenge their difficulties and try hard to overcome them, encouraged learners and motivated them to use compensation strategies more frequently. Certain strategies were significantly positively correlated to personal stamina such as "use of circumlocution" strategy, "paraphrase", "Use of fillers", "Repetition", "Self-repair", and "False starts". Having a closer look at these strategies, it can be found that these are the strategies employed more frequently by the participants. So, it can be concluded that personal stamina enabled EFL learners use the compensation strategies that help them overcome and challenge their language problems, more frequently than other strategies.

\section{$\underline{\text { Conclusion }}$}

The current study aimed at investigating the compensation strategies used by EFL learners and the relationship between frequency of use of these strategies and learners' personal stamina. For collecting data, participants' response to three oral tasks were transcribed, then analyzed for counting the compensation strategies used and the frequency of use and percentage of each strategy. The correlation 
between the frequency of use of these strategies and learners' personal stamina was examined. Results of the study showed that there was a positive statistically significant correlation at (0.01) level between learners' frequency of use of compensation strategies and personal stamina.

\section{$\underline{\text { Recommendations }}$}

Based on the results of the study, the researcher recommended that:

- Stakeholders in education have to put into consideration and investigate EFL learners' sense of self-efficacy because it is closely related to their language performance in different domains.

O Interest in the EFL classroom should be shifted from the teacher to the learner; there should be a focus on learner strategies not teaching methods and techniques. This is because the use of learning strategies help EFL learners to be autonomous and independent learners and users of the language.

\section{Suggestions for further research}

\section{Based on the results of the study, the following research areas were suggested:}

- A study could be conducted for investigating the relationship between the frequency of use of compensation strategies and other components of self-efficacy such as "self-regulation", "self-confidence"...etc.

o The relationship between EFL learners' use of compensation strategies and language fluency could be investigated.

- A compensation strategies-based program could be designed for EFL learners with low oral proficiency level for enhancing their oral performance and lowering their speaking anxiety. 


\section{References}

Al-Saqqaf, A. A. M. (2015). The Relationship between Oral Communication Strategy Use with Language Motivation and Language Anxiety among Yemeni Postgraduates in Malaysia, Ph.D. Dissertation, Universiti Utara Malaysia.

Bandura, A. (1982). "Self-efficacy mechanism in human agency". American Psychologist,vol. (37), pp. (122-147).

Chang, C. \& Lee, Y. (2007). "A Study of Language Learning Strategies Used by College EFL Learners in Taiwan". Retrieved (22/8/2017) from www.mdu.edu.tw/ ged/other\%20download/bulletin/.../11.pdf

Dornyei, Z \& Scott, M. (1997). "Review Article: Communication Strategies in Second Language: definition and taxonomies", Language Learning, vol. (47), No. (1).

Dornyei, Z. (1995). "On the Teachability of Communication Strategies", TESOL Quarterly, Vol. (29).

Gahungu, O.(n.d.). "The Relationships among Strategy Use, Self- Efficacy, and Language Ability in Foreign Language Learners". Retrieved (16/2/2014) from nau.edu/COE/Curriculum.../Gahungu_Abstract_PDF/

Hua, T. (2012)." Communication Strategies among EFL Students - An Examination of Frequency of Use and Types of Strategies Used", GEMA Online ${ }^{T M}$ Journal of Language Studies, Vol. (12), no. (3).

Hua, T., Nor, N. \& Jaradat, M. (2012). "Communication Strategies mong EFL Students - An Examination of Frequency of Use and Types of Strategies Used", GEMA Online ${ }^{T M}$ Journal of Language Studies, Vol. 12(3), Special Section.

Jee, M. (2015). "Language Learners' Strategy Use and Self-Efficacy:Korean Heritage Learners versus Non-Heritage Learners". Language Research, vol. (51), No. (1), pp. (167-195).

Kaizhu, L. (2016). Oral Communication Strategies of Pre-university Malaysian Chinese Students, M.A. thesis, Faculty of Languages and Linguistics University of Malaya, Kuala Lumpur.

Karbalaei, A. and Taji, T. (2014). "Compensation Strategies: Tracking Movement in EFL Learners' Speaking Skills", Gist Education and Learning Research Journal, ISSN (1692-5777), No. (9), (July- December), pp. (88-102). 
Li, Y. \& Wang, C. (2010). "An Empirical Study of Reading Self-efficacy and the Use of Reading Strategies in the Chinese EFL Context", The Asian EFL Journal Quarterly, vol. 12, Issue 2.

Manchón, R. (2000). "Fostering the autonomous use of communication strategies in the foreign language classroom", Links \& Letters, Vol.(7), Pp. (13-27).

Mistar, J and Umamah, A. (2014). "Strategies of learning speaking skill by Indonesian learners of English and their Contribution to speaking proficiency", TEFLIN Journal, Vol. (25), No. (2).

Mizumoto, A. (2012). "Exploring the effects of self-efficacy on vocabulary learning strategies". Studies in Self-Access Learning Journal,vol. (3), no. (4), pp. (423-437).

Moattarian, A. \& Tahririan, M. (2013). "Communication Strategies Used in Oral and Written Performances of EFL Learners from Different Proficiency Levels: The Case of Iranian EFL University Students", Sheikhbahaee EFL Journal, Vol. (2), No. (1).

Najafabadi, N. (2014). "The Use of Speaking Strategies by Iranian EFL University Students", International Journal of Foreign Language Teaching \& Research, Vol. (3), Issue (5).

Somsai, S. (2011). Strategies For Coping With Face-To-Face Oral Communication Problems Employed By Thai University Students Majoring In English, GEMA Online TM Journal of Language Studies, Vol. 11, no. 3.

Taheri, A and Davoudi, M. (2016). "The Use of Compensation Strategies in the Iranian EFL Learners' Speaking and its Relationship with Their Foreign Language Proficiency", Journal of Education and Practice, ISSN (2222-1735) (Paper), Vol. (7), No. (9).

Taheri, A. \& Davoudi, M. (2016) "The Use of Compensation Strategies in the Iranian EFL Learners' Speakin-+g and its Relationship with Their Foreign Language Proficiency", Journal of Education and Practice, Vol. (7), No. (9).

Tarone, E. (1980). "Communication Strategies, Foreigner Talk and Repair in Interlanguage", Language Learning, Vol. (30).

Thu, N. \& Thu, N. (2016). "Oral English Communication Strategies among Vietnamese Non-majors of English at Intermediate Level", American Journal of Educational Research, Vol. (4), No. (3), pp. (283-287). 
Topkaya , E. (2010). "Pre-Service English Language Teachers' Perceptions of computer Self-Efficacy and General Self-Efficacy", TOJET: The Turkish Online Journal of Educational Technology, v. 9 ISSN. 1, Jan.

Ugla,R, Jafre, N and Abidin, M. (2013)."Study of the Communication Strategies Used by Iraqi EFL Students", International Journal of Evaluation and Research in Education (IJERE), V. (2), No. (1), P.p. (44-49).

Wahyuni, S. (2013) L2 Speaking Strategies Employed By Indonesian EFL Tertiary Students across Proficiency and Gender, Ph.D. Dissertation.

Wang, P. \& Wang, A. (2015). "Investigating the relationship among language learning strategies, English self-efficacy and explicit strategy instruction", Taiwan Journal of TESOL, Vol. (12.), No. (1), pp. (35-62).

yaman, S. Irgin, P. \& Kavasoglu,M. (2013)"Communication Strategies: Implications for EFL University Students", journl of educational sciences research, vol.(3), no. (2).

Yilmaz, C. (2010). "The relationship between language learning strategies, gender, proficiency and self-efficacy beliefs: a study of ELT learners in Turkey", Procedia Social and Behavioral Sciences, Vol. (2), pp. (682-687).

Zarei, A. \& Gilanian, M. (2015). "Self-efficacy as a function of Language Learning Strategy Use", British Journal of Education, Society \&Behavioural Science, vol. (9), No. (3), pp. (223-235). 